\title{
Folate depletion impairs DNA excision repair in the colon of the rat
}

\author{
S-W Choi, Y-I Kim, J N Weitzel, J B Mason
}

\begin{abstract}
BackgroundlAims-Diminished folate status appears to promote colonic carcinogenesis by, as of yet, undefined mechanisms. Impaired DNA repair plays a significant role in the evolution of many colon cancers. Since folate is essential for the de novo synthesis of nucleotides and since folate depletion has previously been associated with excessive DNA strand breaks, it was hypothesised that folate depletion may impair DNA repair. Studies were therefore performed to examine whether folate depletion affects the two major categories of DNA repair.
\end{abstract}

Methods-Study 1: eight weanling male Sprague-Dawley rats were fed on diets containing either 0 or $8 \mathrm{mg}$ folate/kg diet with $1 \%$ succinylsulphathiazole for four weeks. After viable colonocytes had been harvested, DNA excision repair was evaluated by a single cell gel electrophoresis assay. Study 2: eighteen animals were fed on similar diets for five weeks. Also in study 2,18 additional rats were fed on the same defined diet without succinylsulphathiazole for 15 weeks. Weekly injections with the procarcinogen, 1,2dimethylhydrazine ( $20 \mathrm{mg}$ base $/ \mathrm{kg}$ ), were administered to the latter group of animals. Five microsatellite loci from different chromosomes were investigated for instability in hepatic and colonic DNA.

Results-In study 1 , a significantly retarded rate of DNA excision repair was observed in the folate deficient colonocytes compared with controls $(p<0.05)$. In study 2 , there was no evidence of instability at the five microsatellite loci associated with either short or long term folate depletion.

Conclusions-Folate deficiency impairs DNA excision repair in rat colonic mucosa; a similar degree of deficiency, even when administered in conjunction with a colonic carcinogen, did not produce evidence of a widespread defect in mismatch repair.

(Gut 1998;43:93-99)

Keywords: folate; colon cancer; DNA repair; single cell gel electrophoresis; microsatellite instability; rat

Environmental factors, particularly those associated with the diet, are considered to play an important role in colorectal carcinogenesis. ${ }^{12}$ A deficiency of the water soluble vitamin, folate, is among those nutritional factors that have been implicated. ${ }^{3}$ More than ten epide- miological studies have observed an association between diminished folate status and premalignant and malignant changes in several epithelial tissues, including the colon (reviewed by Mason and Levesque ${ }^{4}$ ). In addition, two prospective clinical trials, which have administered folate supplements in a placebo controlled fashion and utilised biomarkers of colon cancer as end points, also suggest that this vitamin can modulate colonic carcinogenesis. ${ }^{56}$ In a rat model of colonic carcinogenesis, folate deficiency enhances the development of colonic dysplasia and cancer, providing convincing evidence for a cause and effect relationship between diminished folate status and colon cancer.

Several potential mechanisms by which folate depletion may enhance colorectal carcinogenesis have been proposed. Folate depletion resulting in defective DNA and/or impaired DNA repair is one such hypothesis. ${ }^{4}$ In support of this hypothesis are observations in cell culture that indicate that folate deficiency induces chromosomal anomalies, ${ }^{7}$ DNA strand breaks, and increased susceptibility to mutagenesis, ${ }^{8}$ as well as laboratory rat studies that indicate that folate depletion results in p53 specific DNA strand breaks. ${ }^{9}$ Since the p53 gene is integrally involved in regulation of the cell cycle as well as DNA repair, such a structural change in the p53 gene may constitute an additional means by which DNA repair could be impaired. The biochemical basis for these DNA anomalies is not known with certainty, but it is probably related to the fact that folate derived one-carbon groups are essential for the de novo synthesis of purines and pyrimidines. ${ }^{10}$ The fact that folate deficiency in humans has been observed to cause both uracil misincorporation into DNA and chromosomal breakage supports the concept that these effects are operative in humans as well. ${ }^{11}$

In the present study we investigated whether folate deficiency produces an impairment of either of the two major types of DNA repair: excision repair and mismatch repair. Anomalies in these repair systems were specifically sought out in the colonic mucosa since the literature on folate and carcinogenesis implicates this tissue as being the most sensitive in this regard and because defects in these two repair systems have been previously implicated in colonic carcinogenesis. ${ }^{12-14}$

\section{Methods}

ANIMALS

This study was approved by the Institutional Animal Care and Use Committee of the Jean Mayer USDA Human Nutrition Research
Accepted for publication 4 February 1998 
Center on Aging at Tufts University. In study 1, eight weanling male Sprague-Dawley rats (46-61 g; Charles River Co., Wilmington, Massachusetts, USA) were randomly assigned to two groups. The control group $(\mathrm{n}=4)$ received an amino acid defined diet containing $8 \mathrm{mg} / \mathrm{kg}$ folate and $1 \%$ succinylsulphathiazole, whereas the folate depleted group $(n=4)$ was fed on an identical diet except that folate was omitted (Dyets, Inc., Bethlehem, Pennsylvania, USA). ${ }^{15}{ }^{16}$ These amino acid defined diets are a well recognised means of predictably inducing folate deficiency. ${ }^{16}$ The non-absorbable sulphonamide is included to facilitate the rapid induction of severe deficiency by reducing bacterial folate synthesis in the gut. ${ }^{15}{ }^{17}$ The basal requirement of folate in the rat has variously been defined as $2-8 \mathrm{mg} / \mathrm{kg}$ of diet. ${ }^{18}{ }^{19}$ Rats were housed individually in wire bottomed stainless steel cages to minimise coprophagy. Diets and water were supplied ad libitum. Body weights were recorded weekly. After four weeks of diet, the rats were placed individually in a carbon dioxide atmosphere chamber until they were rendered unconscious and then they were killed by exsanguination. Blood was collected into vacutainer tubes, centrifuged at $800 \mathrm{~g}$ for 10 minutes at $4^{\circ} \mathrm{C}$ and plasma was stored at $-70^{\circ} \mathrm{C}$ in $0.5 \%$ ascorbic acid for plasma folate assays. Complete blood counts were analysed immediately (System 9000; Serono Baker Diagnostic Inc., Allentown, Pennsylvania, USA). The liver was excised, frozen in liquid nitrogen, and stored at $-70^{\circ} \mathrm{C}$ for hepatic folate assay. The colorectum was excised, opened longitudinally, and the faeces pushed off gently. It was then washed three times with ice cold saline, completely unfolded on a cold glass plate, and the mucosa scraped off gently with glass microscope slides. ${ }^{20}$ Then $0.1-0.2 \mathrm{~g}$ colonic mucosal scrapings were immediately frozen in liquid nitrogen and stored at $-70^{\circ} \mathrm{C}$ for mucosal folate assay. The remainder of the mucosal scrapings were used for the single cell gel electrophoresis assay.

For the second study, 18 weanling male Sprague-Dawley rats were randomly assigned to two groups and placed on amino acid defined diets containing either 0 or $2 \mathrm{mg}$ folate $/ \mathrm{kg}$ with $1 \%$ succinylsulphathiazole for five weeks. Additional rats $(n=18)$ were randomly assigned to two groups and fed on the same two diets without $1 \%$ succinylsulphathiazole. Omission of the sulphonamide in the latter part of study 2 results in the induction of a more mild degree of folate deficiency, ${ }^{16}$ enabling the study to be carried out over a longer period of time. 1,2Dimethylhydrazine (DMH) was administered to the latter two groups of animals every week starting five weeks after initiation of the defined diets, and continued for 15 weeks, as previously described. ${ }^{21}$ Rats were killed as described above, and DNA was extracted from the frozen liver tissue and colonic mucosal scrapings using a conventional DNA extraction kit (Easy-DNA; Invitrogen, San Diego, California, USA). Each of the DNA isolates was $20 \mathrm{~kb}$ or more by agarose gel electrophoresis, and had no RNA contamination. $\mathrm{A}_{260} / \mathrm{A}_{280}$ ratio was 1.8 or above in all instances.

PREPARATION OF SINGLE CELL SUSPENSION

Fresh colonic mucosal scrapings were minced by 60 strokes of sharp scissors and dropped into a $50 \mathrm{ml}$ siliconised centrifuge tube containing $30 \mathrm{ml}$ ice cold phosphate buffered saline with mannitol (PBS-M, $85.5 \mathrm{mmol} / 1$ $\mathrm{NaCl} ; 2.6 \mathrm{mmol} / 1 \mathrm{KCl} ; 8.1 \mathrm{mmol} / 1 \mathrm{Na}_{2} \mathrm{HPO}_{4}$; $1.5 \mathrm{mmol} / 1 \mathrm{KH}_{2} \mathrm{PO}_{4} ; 200 \mathrm{mmol} / 1$ mannitol; $200 \mathrm{U} / \mathrm{ml}$ penicillin; $200 \mathrm{mg} / \mathrm{ml}$ streptomycin; $\mathrm{pH}$ 7.4). The suspension was agitated by mild bubbling of oxygen through a Pasteur pipette for 30 minutes. Pipetting up and down facilitated disaggregation. The suspension was then centrifuged at $75 \mathrm{~g}$ for two minutes. The supernatant was removed and $20 \mathrm{ml}$ ice cold fresh PBS-M was added to the loosely packed cell sediment. The cells were resuspended by gentle oxygen bubbling through the medium for five minutes. ${ }^{20}$ The centrifugation was repeated once more and cells were resuspended in $20 \mathrm{ml}$ cold calcium- and magnesium-free phosphate buffered saline for subsequent single cell gel electrophoresis assay. Every operation was performed at $4^{\circ} \mathrm{C} .^{20}$. Cell viability was examined by the trypan blue exclusion technique, ${ }^{22}$ and cells remained more than $90 \%$ viable for the first 90 minutes after isolation for both folate replete and folate deficient cells.

SINGLE CELL GEL ELECTROPHORESIS ASSAY This method has previously been described and used to quantify nucleotide excision repair. ${ }^{23-25}$ Each single cell suspension was treated with $10 \mu \mathrm{mol} / 1 \mathrm{H}_{2} \mathrm{O}_{2}$ for 10 minutes at $37^{\circ} \mathrm{C}$ and then washed three times with $20 \mathrm{ml}$ cold calcium- and magnesium-free phosphate buffered saline. ${ }^{26}$ After $\mathrm{H}_{2} \mathrm{O}_{2}$ treatment, $0.5 \%$ autologous serum was added to each cell suspension. Each folate deficient suspension was further divided into two: $3 \mu \mathrm{mol} / 1$ thymidine and $30 \mu \mathrm{mol} / 1$ hypoxanthine were added to one of the two folate deficient suspensions to make a "nucleotide pool precursor supplemented" colonocyte suspension. ${ }^{7}$ Folate deficiency has previously been shown to induce deoxyribonucleotide pool imbalances, and this is one of the candidate mechanisms for altered DNA repair. Each cell suspension was incubated in a humidified air tight container (atmospheric composition $95 \% \mathrm{O}_{2}$ and $5 \%$ $\mathrm{CO}_{2}$ ) at $37^{\circ} \mathrm{C}$, and $0.5 \mathrm{ml}$ aliquots were taken in timed sequence (before $\mathrm{H}_{2} \mathrm{O}_{2}$ treatment, immediately after treatment, 30,60, and 90 minutes later) for single cell gel electrophoresis assay. Low melting point agarose $(0.5 \%$; NuSieve, FMC, Rockland, Maine, USA) was added to each freshly prepared suspension of cells at the termination of their incubation, and then the suspension was applied to a fully frosted microscope slide precoated with $1 \%$ regular agarose. After application of a third layer of $0.5 \%$ low melting point agarose, the slides were immersed in a jar containing cold lysing solution $(2.5 \mathrm{~mol} / 1 \mathrm{NaCl}, 100 \mathrm{mmol} / 1$ EDTA, $10 \mathrm{mmol} / 1$ Tris, $1 \%$ sodium sarcosinate, $\mathrm{pH} 10 ; 1 \%$ Triton X-100 was added 
Table 1 Effect of folate deficiency on weight, haemoglobin concentration, and serum, liver, and colon folate concentrations

\begin{tabular}{|c|c|c|c|c|c|c|}
\hline & \multicolumn{2}{|l|}{ Study 1} & \multicolumn{2}{|l|}{ Study $2 A$} & \multicolumn{2}{|l|}{ Study $2 B$} \\
\hline & Control & Deficient & Control & Deficient & Control & Deficient \\
\hline Weight† & $261.8(35.7)$ & $262.0(15.6)$ & $344.1(27.2)$ & $291.3(6.8)^{\star \star}$ & $543.6(24.4)$ & $571.3(31.6)$ \\
\hline Haemoglobin (g/dl) & $13.0(0.4)$ & $11.9(0.9)$ & $14.3(0.7)$ & $10.6(1.9)^{\star \star}$ & $14.9(2.1)$ & $14.8(1.7)$ \\
\hline Serum folate $(\mathrm{ng} / \mathrm{ml})$ & $106.4(18.7)$ & $3.3(1.7)^{\star \star}$ & $73.0(20.3)$ & $10.9(14.2)^{\star \star}$ & $51.8(19.0)$ & $23.9(19.5)^{\star \star}$ \\
\hline Liver folate $(\mu \mathrm{g} / \mathrm{g}) \ddagger$ & $7.6(1.5)$ & $1.2(0.3)^{\star \star}$ & $8.8(2.0)$ & $0.4(0.1)^{\star \star}$ & $5.5(4.4)$ & $1.8(1.0)^{\star}$ \\
\hline Colon folate $(\mathrm{ng} / \mathrm{g}) \ddagger$ & $666.1(92.0)$ & $139.8(55.8)^{\star \star}$ & $702.4(178.3)$ & $13.4(5.8)^{\star \star}$ & $656.3(83.1)$ & $464.3(87.6)^{\star}$ \\
\hline
\end{tabular}

Results are expressed as mean (SEM).

Study 1, excision repair study in severely folate deficient rats; study 2A, mismatch repair study in severely folate deficient rats; study $2 \mathrm{~B}$, mismatch repair study in DMH treated folate deficient rats.

${ }^{\star} \mathrm{p}<0.05 ;{ }^{\star \star} \mathrm{p}<0.01$ control $v$ deficient.

tWeight measured at time of death.

‡Concentration expressed per $\mathrm{g}$ tissue wet weight.

fresh) to lyse the cells and to permit DNA unfolding. The slides were kept at $4^{\circ} \mathrm{C}$ for at least one hour. After the lysis, the slides were placed on a horizontal gel unit for 20 minutes in the fresh electrophoresis buffer $(300 \mathrm{mmol} / 1$ $\mathrm{NaOH}$ and $1 \mathrm{mmol} / 1$ EDTA) for DNA unwinding. Electrophoresis was conducted for five minutes at $25 \mathrm{~V}$ and $300 \mathrm{~mA}$, and the slides were neutralised with Tris buffer $(0.4 \mathrm{~mol} / \mathrm{l}$ Tris/ $\mathrm{HCl}, \mathrm{pH}$ 7.5) and stained with ethidium bromide. ${ }^{27-29}$ All of these steps were conducted under dim light to prevent additional DNA damage. The slides were observed under $250 \times$ magnification in a fluorescence microscope (Olympus Corporation, Lake Success, New York, USA) attached to a video camera connected to a C-Imaging Image Analysis System (Compix Inc., Mars, Pennsylvania, USA). A software application (Simple; Compix Inc.) was used for image processing and data collection. Images of 40 cells per specimen $(20$ cells on each of the duplicate slides) were measured for DNA migration and the length of the image (diameter of the nucleus plus migrated DNA); measurements were in $\mu \mathrm{m} .{ }^{27} 30$

MICROSATELLITE INSTABILITY

Five loci containing di- or tri-nucleotide repeat sequences, representing five different chromosomes were studied. ${ }^{31-33}$ The loci were (chromosome): D1MGH 22 (1); D2MIT 12 (2); IGHE (6); PPY (10); AR (X). Polymerase chain reaction (PCR) was performed as described previously with minor modifications. ${ }^{34-36}$ In brief, each $25 \mu$ l reaction mixture, containing $100 \mathrm{ng}$ DNA, $200 \mu \mathrm{mol} / 1$ each dNTP, 1-1.5 mmol/1 $\mathrm{MgCl}_{2}, 5 \mathrm{pmol}$ unlabelled primers and 0.16 pmol labelled (with $\left[\gamma-{ }^{32} \mathrm{P}\right] \mathrm{ATP}$ ) forward primer, and 1 unit Taq DNA polymerase was amplified for 30 cycles with the following regimen: denaturation at $94^{\circ} \mathrm{C}$ for 30 seconds; annealing at 45 or $55^{\circ} \mathrm{C}$ for 30 seconds; and extension at $72^{\circ} \mathrm{C}$ for 30 seconds. PCR products were separated in $7 \%$ polyacrylamide $/ 7 \mathrm{~mol} / 1$ urea $/ 32 \%$ formamide sequencing gels and detected by autoradiography. Microsatellite instability was assessed by determining whether bands were present in folate deficient DNA that were not present in corresponding folate replete DNA. A positive case was defined as one showing instability at one or more loci, confirmed in two independently performed PCRs. ${ }^{37}$ Defects in mismatch repair are usually sought in neoplastic tissue itself because the mono- or oligo- clonal nature of a neoplasm makes the identification of microsatellite instability easy and because the likelihood of finding instability is greater. Nevertheless, Vogelstein and colleagues $^{38}$ have recently shown that individuals possessing a predisposition to mismatch repair and colon cancer may display the mismatch phenotype in non-neoplastic tissues. We therefore hypothesised that the systemic nature of a folate deficiency may produce a defect in mismatch repair that would be evident throughout the colonic mucosa.

\section{PLASMA AND TISSUE FOLATE}

Plasma folate concentration was determined by a conventional microbiological microtitre plate assay using Lactobacillus casei. ${ }^{39}$ Hepatic and colonic mucosal folate concentrations were measured by the same microbial assay after extraction of tissue folates in 10 and 4 volumes of fresh folate extraction buffer $(5 \mathrm{mmol} / 1$

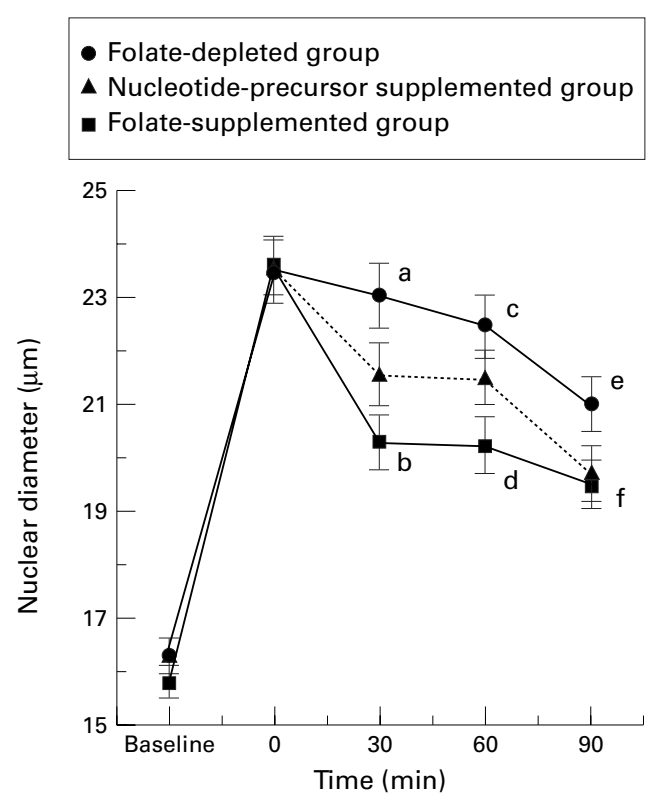

Figure 1 Recovery of nuclear size after $\mathrm{H}_{2} \mathrm{O}_{2}$ treatment. Results are means (SEM). The recovery of nuclear length after $\mathrm{H}_{2} \mathrm{O}_{2}$ damage was significantly delayed in the folate deficient group compared with the folate supplemented group ( $p=0.03$, repeated measures of analysis). Significant differences between the two groups were also evident at each time point (indicated by different superscript letters, $p<0.05$, Student's $t$ test). The mean values for nuclear length in the nucleotide precursor supplemented folate deficient group were intermediate between the folate deficient and folate supplemented groups, and there were no significant differences between this group and the other two. 

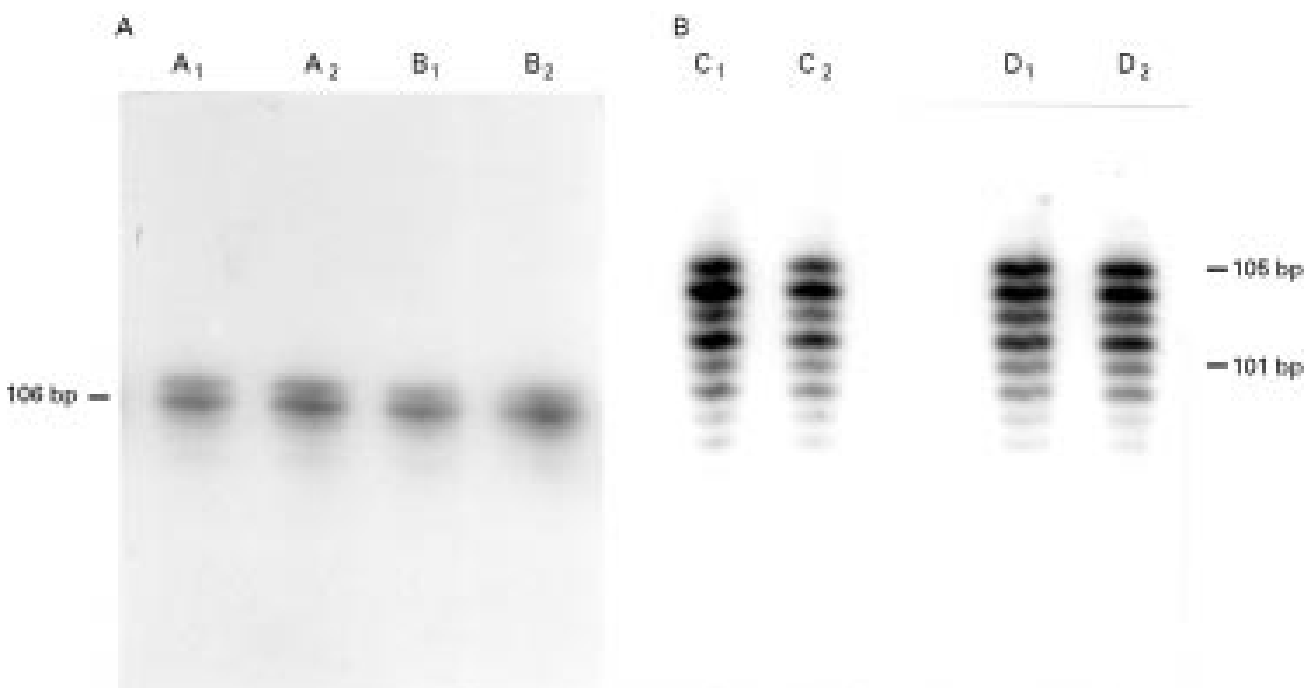

Figure 2 Microsatellite loci investigated in this study. (A) AR locus in X chromosome of male rats. $A_{1}$ and $A_{2}$ are from control rats, and $B_{1}$ and $B_{2}$ are from folate deficient rats. (B) IGHE locus in chromosome 6. $C_{1}$ and $C_{2}$ are from control rats, and $D_{1}$ and $D_{2}$ are from folate deficient rats. The microsatellite amplification products from the folate deficient rats and the folate replete controls were identical. There was no evidence of microsatellite instability at the five loci used in this study.

ß-mercaptoethanol and $0.1 \mathrm{~mol} / 1$ sodium ascorbate in $0.1 \mathrm{~mol} / 1$ [bis-(2-hydroxyethyl)imino] tris(hydroxymethyl)methane, $\mathrm{pH} 7.85$ ) respectively, followed by treatment with chicken pancreas conjugase to convert all the polyglutamates to their corresponding mono- and di-glutamate derivatives. ${ }^{39}{ }^{40}$ The latter method has been used extensively to quantify tissue folate concentrations. ${ }^{4142}$

\section{STATISTICAL EVALUATION}

Differences in the means in folate status, body weight, and haemoglobin level between control and deficient groups of rats were examined by two tailed Student's $t$ tests. Significant differences in the recovery of nuclear length between the control and folate deficient groups were determined by repeated measures analysis of variance. A level of significance was set at $\mathrm{p}<0.05$ in all instances. Statistical analysis was performed using Systat 5 for the Macintosh (Systat, Inc., Evanston, Illinois, USA).

\section{Results}

SINGLE CELL GEL ELECTROPHORESIS (STUDY 1)

All rats appeared healthy in this study and no weight loss or premature death occurred. Similarly, the mean blood haemoglobin concentrations were not significantly different between the control and deficient animals. Nevertheless, the deficient diet led to a greater than $90 \%$ decrease in mean plasma folate $(\mathrm{p}<0.01)$ and an $80 \%$ decrease in hepatic and colonic folate $(p<0.01)$. These observations indicate that, although the folate deficiency in study 1 was not severe enough to make the animals ill, it nevertheless was of sufficient magnitude to deplete both the liver and colon of folate (table 1). As previously described, ${ }^{43}$ nuclear DNA in the single cell gel electrophoresis assay appeared as a brightly fluorescent well circumscribed circle before $\mathrm{H}_{2} \mathrm{O}_{2}$ treatment. After peroxide treatment, the DNA became fragmented and appeared like a comet. The length of the comet is a direct reflection of the severity of DNA strand breakage, and excision repair capacity is measured by the speed with which the extended length recovers over time. ${ }^{27}$ As shown in fig 1 , folate deficient cells showed delayed recovery of nuclear lengths compared with the folate supplemented control cells $(\mathrm{p}=0.03$, repeated measures ANOVA). Even after 90 minutes, the folate deficient colonocytes had not yet recovered to the extent that the control cells had $(\mathrm{p}<0.05)$. This observation indicates that DNA excision repair was significantly impaired in folate deficient colonocytes compared with controls. On the other hand, the mean values for nuclear length observed in the nucleotide precursor supplemented folate deficient colonocytes were intermediate between the folate deficient group and the control group (fig 1, small triangles), and there were no significant differences between these values and those of the latter two groups ( $p>0.05$, repeated measures ANOVA). Similarly the nucleotide precursor groups did not show any significant differences compared with the control or folate deficient groups at any individual time point $(\mathrm{p}>0.05)$.

\section{MISMATCH REPAIR STUDY (STUDY 2)}

In the second experiment, five week old rats, also treated with succinylsulphathiazole, showed a significant decrease in body weight, haemoglobin level, and folate levels of the serum, liver, and colon (table 1). This was a somewhat more severe degree of depletion than in study 1 , reflecting an additional week on the folate deficient diet. In contrast, 15 week old rats without succinylsulphathiazole did not show any differences in body weight and haemoglobin level, but folate levels of serum, liver, and colon were significantly decreased (table 1). Figure 2A shows the amplified AR microsatellite locus in the $\mathrm{X}$ chromosome, split by two bands, which is common in microsatellite amplification. Figure 2B shows another amplified microsatellite locus, $I G H E$, in chromosome 6 . In the loci examined in fig $2 \mathrm{~A}$ and 
2B, an identical pattern of amplification is evident for the folate deficient and folate replete animals. In a survey of five distinct microsatellite loci, including $A R$ and $I G H E$, microsatellite instability was not found in either the hepatic tissue or the colonic tissue. In the first part of study 2 (folate deficiency alone), extra bands were lacking in the amplified loci from DNA of folate deficient rats compared with control rats, regardless of whether the comparisons were with the same tissue (colon-colon, liver-liver) or a different tissue (colon-liver). In the second part of study 2 , in which rats were variously exposed to long term folate deficiency and $\mathrm{DMH}$ or to $\mathrm{DMH}$ alone, instability was also not found in either the $\mathrm{DMH}$ treated group or the DMH treated folate deficient group. In the instance of the DMH exposed groups, comparisons were made between colon and liver, since $\mathrm{DMH}$ is largely a colon-specific carcinogen at the doses used in this study. ${ }^{424}$

\section{Discussion}

Colorectal cancer is felt to evolve through the stepwise acquisition of mutations and deletions at certain critical genetic loci, many of which have been recently identified. ${ }^{45}{ }^{46}$ The primary carcinogens and the mechanisms by which colorectal carcinogenesis proceeds, however, are poorly understood. Since evidence is rapidly accumulating that diminished folate status enhances colonic carcinogenesis, ${ }^{34}$ we investigated the effect of folate deficiency on the major types of DNA repair present in colonic mucosal cells. Our observations show that folate deficiency alone is sufficient to impair DNA excision repair in this tissue. In contrast, no evidence of defects in the mismatch repair system were observed. The apparent resistance of mismatch repair was even evident when the folate deficiency was prolonged and was present in conjunction with a chemically induced predisposition to cancer.

Defects in DNA repair have been strongly implicated in colorectal carcinogenesis. ${ }^{47}$ Two major categories of DNA repair systems, excision repair and mismatch repair, have been described for mammalian cells. Excision repair removes damaged bases and short sequences and replaces them with normal ones. ${ }^{48}$ In contrast, mismatch repair specialises in correcting errors made when DNA is replicated. The two repair systems are not entirely independent, since recent studies have indicated that, at least in prokaryotes, the molecular processes of mismatch repair are related to the molecular mechanisms of excision repair in a subtype of excision repair called transcription coupled repair. $^{1449}$

The single cell gel electrophoresis assay is a rapid and sensitive technique for measuring and analysing DNA breakage in mammalian cells and has proved to be useful in measuring the DNA excision repair capacity from chemically and radiation induced DNA lesions. ${ }^{27-29}$ Two subtypes of excision repair are known to exist: nucleotide excision repair and base excision repair. Although the predominant mode of repair of $\mathrm{H}_{2} \mathrm{O}_{2}$ treatment is thought to be nucleotide excision repair, ${ }^{50}$ some base excision repair is almost certainly a factor. The single cell gel electrophoresis assay cannot adequately distinguish between the two, so we merely refer in this study to the term "excision repair", a term that encompasses both subtypes. In this microgel electrophoresis technique, cells are embedded in agarose gel on microscope slides, lysed, and electrophoresed under alkaline conditions. Cells with increased DNA damage display increased migration of the DNA from the nucleus towards the anode. The length of DNA migration has been shown to reflect the amount of DNA breakage in the cell. ${ }^{28}{ }^{30}$ In the first study reported in this paper, we produced oxidative damage to the DNA of isolated colonocytes with dilute $\mathrm{H}_{2} \mathrm{O}_{2}$ and observed DNA excision repair activity with the single cell gel electrophoresis assay, comparing the repair activity between folate deficient and folate replete colonocytes. $\mathrm{H}_{2} \mathrm{O}_{2}$ produces a wide spectrum of DNA damage: strand breaks, purine and pyrimidine base damage, as well as damage to the deoxyribose moiety have all been described. $\mathrm{H}_{2} \mathrm{O}_{2}$ can also release all four bases from DNA (the pyrimidines especially, thymidine appears to be most susceptible) and cleave the DNA backbone. ${ }^{51}{ }^{52}$ Nucleotide excision repair, which recognises and repairs large bulky lesions in DNA, is therefore a major cellular defence mechanism against this oxidising agent. ${ }^{50}$

Our folate deficient rats in study 1 showed significantly decreased plasma, hepatic, and colonic folate concentrations compared with the folate supplemented groups, even though body weight and haemoglobin level were not different. The single cell gel electrophoresis assay of DNA from these rats showed that folate deficiency delayed the rate of DNA repair activity in rat colonocytes. Although the initial extent of DNA damage was identical in the folate deficient and folate supplemented groups, a significant difference in the degree of recovery from this insult was evident between the control and folate deficient group as early as 30 minutes after the damage. In this experiment, both control and folate deficient colonocytes showed progressive recovery over time, but the folate deficient cells displayed a significant retardation in the rate of recovery that was still apparent one and half hours after the damage had been inflicted. It remains to be determined whether a more modest degree of folate deficiency produces a similar defect in excision repair. We recently reported the appearance of strand breaks within the p53 gene in rat colon resulting from a similar degree of folate deficiency. ${ }^{9}$ Since the presence of strand breaks represents a dynamic balance between ongoing DNA damage and the repair mechanisms that correct the damage, one could reasonably speculate that the strand breaks observed in our prior study reflect, at least in part, impaired DNA excision repair.

Hypoxanthine is a precursor which bypasses the need for folate dependent purine biosynthesis, and thymidine precludes the need for de novo thymidine synthesis, another folate dependent reaction. ${ }^{53}$ In an in vitro study, Chinese hamster ovary cells grown in folate 
deficient medium showed various types of chromosomal aberrations, but cells grown in hypoxanthine supplemented folate deficient medium exhibited a low frequency of damaged mitoses. ${ }^{7}$ In our experiment we added hypoxanthine as a purine precursor and thymidine as a pyrimidine precursor to the aliquots of a folate deficient single cell suspension. The values for single cell gel electrophoresis assay observed in the precursor supplemented colonocytes were intermediate between the folate deficient group and the controls, and did not show any significant difference compared with either of those groups. It is well known that the addition of these precursors, in the concentrations used in this study, can reverse some of the effects of folate deficiency, ${ }^{7}$ but in this instance, the addition of nucleotide precursors does not appear to have been sufficient to reverse the observed effects of folate deficiency completely. These observations suggest that folate deficiency disrupts excision repair partly, but not wholly, by altering the cellular pool of deoxyribonucleotides, a well known effect of folate deficiency. ${ }^{54-56}$

The stability of short repeated sequences (microsatellites) provides an excellent indicator of mismatch repair proficiency, as these sequences are prone to misalignment during DNA replication. Such replication errors, as shown by microsatellite instability, are found in $43-71 \%$ of colorectal cancers from patients with hereditary non-polyposis colorectal cancer and in $9-13 \%$ of seemingly sporadic colorectal cancers. ${ }^{57-59}$ Our search for such instability in folate deficient animals produced negative results as did the survey in animals where folate deficiency was prolonged and was present in conjunction with a carcinogen induced predisposition to colon cancer. In order to create such a predisposition, we used the well established DMH rodent model of colorectal cancer. ${ }^{60}{ }^{61}$ The DMH rodent model of colorectal carcinogenesis mimics closely that of humans but has been shown not to induce microsatellite instability by itself. ${ }^{62}$ There was no evidence of instability at the five loci we chose, and therefore folate deficiency, with or without the synergism of a chemically induced predisposition to colon cancer, does not appear to disrupt mismatch repair. We intentionally surveyed microsatellite loci on five different chromosomes, since this has been the practice of other investigators searching for defects in mismatch repair ${ }^{63}{ }^{64}$; however, we cannot exclude the possibility that a more exhaustive survey of other microsatellites would have produced some evidence of instability, or that another means of assessing defects in mismatch repair or other levels of folate deficiency may have detected some abnormalities. In fact a moderate, rather than severe, level of folate deficiency may be more relevant to the human situation.

In summary, folate deficiency alone is a sufficient force to create an impairment in DNA excision repair in the colonic mucosa. The mechanism(s) by which this effect is mediated has not entirely been revealed by our study but may, in part, be related to the disruption of intracellular nucleotide pools. Previous reports of genomic and gene specific DNA strand breaks associated with folate deficiency ${ }^{9}$ may be related to this phenomenon. Whether the disruption in DNA repair induced by folate deficiency is a means by which diminished folate status enhances colorectal carcinogenesis remains a provocative, but untested, hypothesis.

This project has been supported in part by a National Cancer Institute grant (1U01-CA63812-01 to J B M), the American Institute for Cancer Research (to J B M), and the US Department of Agriculture, Agriculture Research Service (Contract 53-3K06-01, to J B M). J N W was supported in part by a Clinical Investigator Award No 1 K08 CA1574 from the NCI. The contents of this publication do not necessarily reflect the views or policies of the US Department of Agriculture, nor does mention of trade names, commercial products, or organisations imply endorsement by the US Government. This work was presented in part at the 96th Annual Meeting of the American Gastroenterology Association, May 19-22, 1996, San Francisco, California, USA, and published in abstract form in Gastroenterology 1996;110:A537.

1 Giovannucci E, Stampfer MJ, Colditz GA, et al. Folate, methionine, and alcohol intake and risk of colorectal methionine, and alcohol intake and risk of

2 Shannon J, White E, Shattuck AL, et al. Relationship of food Shannon J, White E, Shattuck AL, et al. Relationship of food
groups and water intake to colon cancer risk. Cancer Epidemiology, Biomarkers and Prevention 1996;5:495-502.

3 Cravo ML, Mason JB, Selhub J, et al. Folate deficiency enhances the development of colonic neoplasia in dimethylhydrazine-treated rats. Cancer Res 1992;52:50026.

4 Mason JB, Levesque T. Folate: effects on carcinogenesis and the potential for cancer chemoprevention. Oncology 1996; 10:1727-43

5 Cravo M, Fidalgo P, Pereira AD, et al. DNA methylation as an intermediate biomarker in colorectal cancer: modulation by folic acid supplementation. Eur F Cancer Prev 1994; 3:473-9.

6 Paspatis GA, Karamanolis DG. Folate supplementation and adenomatous colonic polyps. Dis Colon Rectum 1994;37: $1340-1$

7 Libbus B, Borman L, Ventrone CH, et al. Nutritional folatedeficiency in Chinese hamster ovary cells. Cancer Genet Cytogenet 1990;46:231-42.

8 Branda R, Blickensderfer F. Folate deficiency increases genetic damage caused by alkylating agents and $\gamma$-irradiation in Chinese hamster ovary cells. Cancer Res 1993;53:5401-8

9 Kim YI, Pogribny IP, Basnakian AG, et al. Folate deficiency in rats induces DNA strand breaks and hypomethylation
within the p53 tumor suppressor gene. Am $\mathcal{F}$ Clin Nutr 1997;65:46-52

10 Shane B, Stoktad ELR. Vitamin $\mathrm{B}_{12}$-folate interrelationships. Annu Rev Nutr 1985;5:115-41.

11 Blount BC, Mack MM, Wehr CM, et al. Folate deficiency causes uracil misincorporation into human DNA and chromosome breakage: implications for cancer and neuronal mosome breakage: implications for cancer and ne
damage. Proc Natl Acad Sci USA 1997;94:3290-5.

12 Fishel R, Lescoe MK, Rao MRS, et al. The human mutator gene homolog MSH 2 and its association with hereditary nonpolyposis colon cancer. Cell 1993;75:1027-38.

13 Ionov Y, Peinado MA, Malkhosyan S, et al. Ubiquitous somatic mutations in simple repeated sequences reveal a new mechanism for colonic carcinogenesis. Nature 1993; 363:558-61.

14 Mellon I, Rajpal DK, Koi M, et al. Transcription-coupled repair deficiency and mutations in human mismatch repair genes. Science 1996;272:557-60.

15 Walzem RL, Clifford AJ. Folate deficiency in rats fed diets containing free amino acids or intact proteins. 7 Nutr 1988; 118:1089-96.

16 Clifford A, Wilson D, Bills N. Repletion of folate-depleted rats with an amino acid-based diet supplemented with folic rats with an amino acid-based diet

17 Wright LD, Skeggs HR, Sprague KL. The effect of feeding succinylsulfathiazole to rats receiving purified diets high in carbohydrate, protein, fat or protein and fat. $\mathcal{F}$ Nutr 1945;9: $432-9$.

18 American Institute of Nutrition: Report of the American Institute of Nutrition ad hoc committee on standards for nutritional studies. F Nutr 1977;107:1340-8.

19 Reeves PG, Nielsen FH, Fahey GC. AIN-93 purified diets for laboratory rodents: final report of the American Institute of Nutrition ad hoc writing committee on the reformulation of the AIN-76A rodent diet. 7 Nutr 1993;123:1939-51.

20 Perret V, Lev R, Pigman W. Simple method for the preparation of single cell suspensions from normal and tumorous
rat colonic mucosa. Gut 1977; 18:382-5.

21 Kim YI, Salomon RN, Graeme-Cook F, et al. Dietary folate protects against the development of macroscopic colonic protects against the development of macroscopic colonic
neoplasia in a dose responsive manner in rats. Gut 199639: 732-40. 
22 Culvenor JG, Weidemann MJ. Phytohaemagglutinin stimulation of rat thymus lymphocytes glycolysis. Biochim Biophys Acta 1976;437:354-63.

23 Speit G, Hartmann A. The contribution of excision repair to the DNA effects seen in the alkaline single cell gel test (comet assay). Mutagenesis 1995;19:555-9.

24 Singh NP, McCoy MT, Tice RR, et al. A simple technique for quantitation of low level of DNA damage in individual cells. Exp Cell Res 1988;175:184-91.

25 Anderson D, Yu TW, Phillips BJ, et al. The effect of various antioxidants and other modifying agents on oxygenradical-generated DNA damage in human lymphocytes in the COMET assay. Mutat Res 1994;307:261-71.

26 Kruszewski M, Green MHL, Lowe JE, et al. DNA strand breakage, cytotoxicity and mutagenecity of hydrogen peroxide treatment at $4^{\circ} \mathrm{C}$ and $37^{\circ} \mathrm{C}$ in L5178Y sublines. Mutat Res 1994;308:233-41.

27 Singh NP, Danner DB, Tice RR, et al. DNA damage and repair with age in individual human lymphocytes. Mutat Res 1990;237:123-30.

28 Vijayalaxmi, Tice RR, Strauss GHS. Assessment of radiation-induced DNA damage in human blood lymphocytes using the single-cell gel electrophoresis tech-

29 Hartmann A, Speit G. Genotoxic effects of chemicals in the single cell gel (SCG) test with human blood cells in relation to the induction of sister-chromatid exchange (SCE). Mutat Res 1995;346:49-59.

30 Kreja L, Selig C, Nothdurft W. Assessment of DNA damage in canine peripheral blood and bone marrow after total body irradiation using the single-cell gel electrophoresis technique. Mutat Res 1996;359:63-70.

31 Beckmann JS, Weber JL. Survey of human and rat microsatellites. Genomics 1992;12:627-631.

32 Maihara T, Andoh Y, Yokoi N, et al. Fifty-six new microsatellite markers in the rat genetic linkage map. Transplant Proc 1995;27:1502-4.

33 Serikawa T, Kuramoto T, Hilbert P, et al. Rat gene mapping using PCR-analyzed microsatellites. Genetics 1992;131: using $P$.

34 Mao L, Lee DJ, Tockman MS, et al. Microsatellite alteration as clonal markers for the detection of human cancer. Proc as clonal markers for the detection of

35 Chong JM, Fukayama M, Hayashi Y, et al. Microsatellite instability in the progression of gastric carcinoma. Cancer Res 1994;54:4595-7.

36 Jacoby RF, Marshall DJ, Kailas S, et al. Genetic instability associated with adenoma to carcinoma progression in hereditary nonpolyposis colon cancer. Gastroenterology 1995; 109:73-82.

37 Suzuki H, Harpaz N, Tarmin L, et al. Microsatellite instability in ulcerative colitis-associated colorectal dysplasias and cancers. Cancer Res 1994;54:4841-4.

38 Parson $\mathrm{R}, \mathrm{Li}$ G, Longley $\mathrm{M}$, et al. Mismatch repair deficiency in phenotypically normal human cells. Science 1995;268:738-40.

39 Tamura T. Microbiological assay of folate. In: Picciano M, Stokstad E, Gregory J, eds. Folic acid metabolism in health Stokstad E, Gregory J, eds. Folic acid metabolism
and disease. New York: Wiley-Liss, 1990:121-37.

40 Wilson SD, Horne DW. Use of glycerol-cryoprotected Lactobacillus casei for microbiological assay of folic acid. Clin Chem 1982;28:1198-200.

41 Kim YI, Christmas JK, Fleet JC, et al. Moderate folate deficiency does not cause global hypomethylation of hepatic and colonic DNA or c-myc-specific hypomethylation of colonic DNA in rats. Am f Clin Nutr 1995;61:1083-90.

42 Kim YI, Pogribny IP, Salomon RN, et al. Exon-specific DNA hypomethylation of the p53 gene of rat colon induced by dimethylhydrazine. Am $\mathscr{f}$ Pathol 1996;149: 1129-37.

43 Gedik CM, Ewen SWB, Collins AR. Single-cell gel electrophoresis applied to the analysis of UV-C damage and its repair in human cells. Int f Radiat Biol 1992;62:313-20.
44 Martin MS, Martin F, Michiels R, et al. An experimental mode for cancer of the colon and rectum. Digestion 1973;8: mode for

45 Fearon ER, Vogelstein B. A genetic model for colorectal tumorigenesis. Cell 1990;61:759-67.

46 Hamilton SR. Molecular genetics of colorectal carcinoma. Cancer 1992;70(suppl 5):1216-21.

47 Ames BN, Shigenaga MK, Gold LS. DNA lesions, inducible DNA repair, and cell division: three key factors in mutagenesis and carcinogenesis. Environ Health Perspect 1993;101(suppl 5):35-44.

48 Craig N, Johnson S, Komachi K, et al. Basic genetic mechanisms. In: Alberts B, Bray D, Lewis J, et al, eds. Molecular biology of the cell. New York and London: Garland Publishing, 1994:223-90.

49 Mellon I, Champe GN. Products of DNA mismatch repair genes mutS and mutL are required for transcriptioncoupled nucleotide-excision repair of the lactose operon in Escherichia coli. Proc Natl Acad Sci USA 1996;93:1292-7.

50 Lin JJ, Sancar A. A new mechanism for repairing oxidative damage to DNA: (A)BC exinuclease removes AP sites and thymin

51 Imlay JA, Linn S. DNA damage and oxygen radical toxicity. Science 1988;240:1302-9.

52 Sarker AH, Watanabe S, Seki S, et al. Oxygen radicalinduced single-strand DNA breaks and repair of the damage in a cell-free system. Mutat Res 1995;337:85-95.

53 Borman LS, Branda RF. Nutritional folate deficiency in Chinese hamster ovary cells. I. Characterization of the pleiotropic response and its modulation by nucleic acid precursors. F Cell Physiol 1989;140:335-43.

54 James SJ, Larry Yin. Diet-induced DNA damage and altered nucleotide metabolism in lymphocytes from methyl-donor-deficient rats. Carcinogenesis 1989;10:120914 .

55 James SJ, Miller BJ, Cross DR, et al. The essentiality of folate for the maintenance of deoxynucleotide precursor pools, DNA synthesis, and cell cycle progression in PHA-stimulated lymphocytes. Environ Health Perspect 1993;101 (suppl 5):173-8.

56 James SJ, Basnakian AG, Miller BJ. In vitro folate deficiency induces deoxyribonucleotide pool imbalance, apoptosis, and mutagenesis in Chinese hamster ovary cells. Cancer Res 1994;54:5075-80

57 Aaltonen LA, Peltomäki P, Mecklin JP, et al. Replication errors in benign and malignant tumors from hereditary nonpolyposis colorectal cancer patients. Cancer Res 1994; 54:1645-8.

58 Branch P, Hampson R, Karran P. DNA mismatching binding defects, DNA damage tolerance, and mutator phenotypes in human colorectal carcinoma cell lines. Cancer Res 1995;55:2304-9.

$59 \mathrm{Kim} \mathrm{H}$, Jen J, Vogelstein B, et al. Clinical and pathological characteristics of sporadic colorectal carcinomas with DNA replication errors in microsatellite sequences. $A m \mathcal{F}$ Pathol 1994;145:148-56.

60 Rogers KJ, Pegg AE. Formation of $\mathrm{O}^{6}$-methylguanine by alkylation of rat liver, colon, and kidney DNA following administration of 1,2-dimethylhydrazine. Cancer Res 1977; 37:4082-7.

61 Rogers AE, Nauss KM. Rodent models for carcinoma of the colon. Dig Dis Sci 1985;30:87-102S.

62 Okamoto M, Ohtsu H, Miyaki M, et al. No allelic loss at the p53 locus in 1,2-dimethylhydrazine-induced mouse colon tumors: PCR-SSCP analysis with sequence-tagged microsatellite site primers. Carcinogenesis 1993;14:1483-6.

63 Thibodeau SN, Bren G, Schaid D. Microsatellite instability in cancer of the proximal colon. Science 1933;260:816-19.

64 Schlegel J, Stumm G, Scherthan H, et al. Comparative genomic in situ hybridization of colon carcinomas with replication error. Cancer Res 1995;55:6002-5. 